\title{
The Impact of Self-Directed Learning Readiness on Critical Thinking and Self-Efficacy among the Students of the School of Physical Education and Sports
}

\author{
Mehmet Behzat Turan ${ }^{1} \&$ Kenan Koç ${ }^{1}$ \\ ${ }^{1}$ Erciyes University, Physical Education and Sport Department, Kayseri, Turkey \\ Corresponde: Mehmet Behzat Turan, ${ }^{1}$ Erciyes University, Physical Education and Sport Department, 38039, Kayseri, \\ Turkey. E-mail: behzatturan@erciyes.edu.tr
}

Received: May 8, 2018

Accepted: November 16, 2018

Online Published: December 5, 2018

doi:10.5430/ijhe.v7n6p98

URL: https://doi.org/10.5430/ijhe.v7n6p98

\begin{abstract}
The aim of this study was to examine the impact of self-directed learning readiness on critical thinking and general self-efficacy among the students of the School of Physical Education and Sports. In line with this aim, the research sample consisted of 419 students who were randomly selected from the School of Physical Education and Sports in Erciyes University. To collect data, the study used Self-Directed Learning Readiness Scale, Critical Thinking Scale, General Self-Efficacy Scale and 'Personal Information Form' created by the researcher.

The data obtained through the Personal Information Form was statistically analyzed using SPSS 20.0 package program. The candidates' personal information and inventory total scores and factor points were presented by calculating frequency (f) and percentage (\%) values. Pearson Moment Correlation Coefficient analysis (r) was performed to indicate the relationship between the points obtained from the scales while multiple regression analysis was performed to identify whether the points are predictor of each other. $(\beta)$

The study found a positive significant relationship between self-directed learning readiness and critical thinking. A positive significant relationship was also found between self-directed learning readiness and general self-efficacy. Finally, there was a positive high relationship between general self-efficacy and critical thinking.

The results of the study suggest that self-directed learning readiness affects critical thinking and general self-efficacy characteristics as it influences other aspects related to education. Self-directed learning readiness predicts critical thinking and general self-efficacy by $50.5 \%$. Hence, authentic environments should be created to improve students' self-directed learning readiness when preparing education and training programs especially as a significant aspect of modern education systems in today's world.
\end{abstract}

Keywords: Self-directed learning readiness, critical thinking, general self-efficacy

\section{Introduction}

While being an essential need of human nature, learning is also an indispensable phenomenon for people to maintain their life and adapt to changing circumstances. With the advance of science and technology in this age, information that people need to learn is also evolving. Accordingly, people feel obliged to update the information they have in line with their needs. Today, it is possible to access to information through multimedia involving visual, audio and textual elements at the same time. When access to information sources is that easy and fast in such a time and environment, it will be difficult for individuals to keep up with information growth rate only through the education provided at school in the learning process (Doğan, 2002). Furthermore, uncertainty of information quality and expanding amount of information can pose major problems for learners. However, individuals who learn to learn can select and organize information that is meaningful and valuable for themselves from this infinite amount of information as they are aware of their own intellectual processes and recognize their defects and competences. Therefore, in light of the statement of Alvin \& Toffler (1996) that "The illiterate of the $21^{\text {st }}$ century will not be those who cannot read and write, but those who cannot learn, unlearn, and relearn", it is necessary that people living in the information society are capable of "learning to learn" and embrace the principle of "continuity of learning" (Özden, 2005; Tuncel, 2010). 
'Learning to learn' is the ability to organise one's own learning, manage time and information and become aware of learning processes and requirements, and also forms the core of lifelong learning (Coşkun, 2009). Lifelong learning skills include fundamental competences of individuals in cognitive, emotional and psychomotor areas. One of these competences is self-directed learning. Cresson \& Dean (2000) maintain that one of the fundamental concepts of lifelong learning is self-directed learning which is among the most appropriate approaches to be used in adult education.

Radial \& Volet (2009) define self-directed learning simply as "learning how to learn". Malcolm Knowles (1975) describes self-directed learning as "a process in which individuals take the initiative without the help of others in diagnosing their learning needs, formulating goals, identifying human and material resources, and evaluating learning outcomes". In addition, self-direction means that the individual can take the whole responsibility in the learning process (Merriam \& Brockett, 2007; Murray, 2015). Merriam, Caferella \& Baumgartner (2007) describe the students with high self-direction as "individuals who willingly make or implement plans with the help of an expert or on their own, and supervise their own learning". Self-directed learning is the way of acquiring new information, ideas, abilities, attitudes and experiences for most adults. Self-directed individuals can display moral autonomy and diverse emotional and intellectual characteristics (Murray, 2015). On the other hand, Fisher defines the concept of self-directed learning readiness as the degree to which the individual possesses the tendency, abilities and personality characteristics which are necessary for self-directed learning skills. Self-directed learning has personal, social and political dimensions and contexts. It is emphasized that the balance between them is of importance to self-directed learning readiness (Wiley, 1982).

Individuals can succeed in learning if they become aware of their cognitive processes. Those who become aware of their own learning can also be successful in academic and daily life. On the other hand, one of the goals of education is raising individuals who constantly think, put their ideas into practice and thus achieve personal and social development (Güven \& Kürüm 2004). Possessing such skills require conscious effort and organization. In this respect, critical thinking is necessary and important for all individuals in academic and daily life. It is considered that having self-directed learning readiness depends on acquiring certain preliminary information, skills and attitudes. Individuals should acquire cognitive and emotional characteristics required by self-directed learning to have self-directed learning readiness. These characteristics are described as skills such as critical thinking, curiosity, assertiveness and motivation, persistence and responsibility in learning, self-efficacy for learning, and being reflective (Gürlen, 2010). Self-directed learning process should be constructed considering the individual's intellectual characteristics and critical thinking skills (Hendricson, 2007).

Taking into account the characteristics of critical thinking, it is found that critical thinking is a significant variable for self-directed learning readiness. In self-directed learning process, the individual is expected to construct information in line with their own cognitive strategies and skills. In this context, it is important that the individual display critical thinking attitudes and question information, evaluate ideas rationally, pass what they learn through a mental filter and assess the whole process.

Bandura (1997), on the other hand, claims that self-efficacy belief plays a vital role in the development of self-directed learners. The perception of and belief in general self-efficacy are important in terms of learning skills, desire for success and intellectual development. While general self-efficacy predicts that the individual can achieve a task depending on their motivation for that task, it also determines their effort, persistence, strategy and performance for the task (Bandura, 1997; Sariolghalam \& Noruzi, 2010).

In light of these explanations, this study aimed to investigate the impact of self-directed learning readiness of the students in the School of Physical Education and Sports on their critical thinking and general self-efficacy, and determine the degree of such impact if there is any. A review of relevant literature shows that there are few studies on the subject and particularly in the field of physical education and sports. Hence, we believe that this study will contribute to the body of literature in this area.

\section{Material-Method}

\subsection{Study Group}

In the study, relational screening model was used. The model can be defined as "a screening model aiming to determine the existence and/or level of covariance between two or among more than two variables" (Karasar, 2007).

The study was a descriptive one as it attempts to examine the impact of self-directed learning readiness on critical thinking and general self-efficacy among the students of the School of Physical Education and Sports and to assess the relationships between the demographic characteristics of the candidates. 


\subsection{Data Collection Tools}

When conducting the questionnaires in the study, the researchers tried to create a healthy evaluation process for the candidates by making necessary explanations to each candidate in a broad time period, without making any rush. In addition, favourable conditions were created so that the candidates could fill the forms in a comfortable atmosphere. To collect data, the study used Self-Directed Learning Readiness Scale, Critical Thinking and General Self-Efficacy Scale and Socio-Demographic Information Form.

\subsection{Formation of Volunteer Groups:}

The research was conducted on the study group which was made up of the candidates in the $1^{\text {st }}, 2^{\text {nd }}, 3^{\text {rd }}$ and $4^{\text {th }}$ grades in the departments of Physical Education and Sports Teaching, Coaching Education, Sports Management and Recreation Education in the School of Physical Education and Sports in Erciyes University. A total of randomly chosen 419 students out of 1470 students in the School of Physical Education and Sports participated in the study.

Table 1. Socio-Demographic Characteristics of the Participants

\begin{tabular}{|c|c|c|c|}
\hline & Variables & $\mathbf{N}$ & $\%$ \\
\hline \multirow{2}{*}{ Gender } & Male & 262 & 62.5 \\
\hline & Female & 157 & 37.5 \\
\hline \multirow{2}{*}{ Age } & $18-21$ & 155 & 37.0 \\
\hline & $22-25$ & 264 & 63.0 \\
\hline \multirow{4}{*}{ Department } & Physical Education and Sports Teaching & 106 & 25.3 \\
\hline & Coaching Education & 104 & 24.8 \\
\hline & Sports Management & 101 & 24.1 \\
\hline & Recreation Management & 108 & 25.8 \\
\hline \multirow{4}{*}{ Grade } & 1 & 77 & 18.4 \\
\hline & 2 & 122 & 29.1 \\
\hline & 3 & 112 & 26.7 \\
\hline & 4 & 108 & 25.8 \\
\hline \multirow{3}{*}{ GPA } & $1.25-1.99$ & 41 & 9.8 \\
\hline & $2.00-2.99$ & 241 & 67.1 \\
\hline & $3.00-4.00$ & 97 & 23.2 \\
\hline
\end{tabular}

\subsection{Socio-Demographic Information Form}

When preparing the socio-demographic information form for the study, self-directed learning readiness, critical thinking and general self-efficacy scales and socio-demographic information forms in literature were examined and a pool for the characteristics of the students to be examined was created. Then, with the help of statistics specialists, a socio-demographic information form was prepared. The form included 5 questions to get information about the age, gender, department, grade and grade point average of the participants.

\subsection{Self-Directed Learning Readiness Scale}

To test the reliability of the Self-Directed Learning Readiness Scale (SDLRS) developed by Fisher et al. (2001), the Cronbach's Alpha coefficients and item-total correlation coefficients were calculated. The results were as follows: .93 for the whole scale; .85 for self-management subscale with item-total correlation coefficients varying between $.36-.68 ; .84$ for willingness for learning subscale with item-total correlation coefficients varying between .31 - .76; and .84 for self-control subscale with item-total correlation coefficients varying between $.39-.73$.

\subsection{California Critical Thinking Disposition Inventory}

"California Critical Thinking Disposition Inventory" is used to assess the individual's disposition to think critically or their critical thinking level rather than measure a skill, which is different from similar critical thinking scales in this respect (Kökdemir, 2003). This inventory emerged as a result of an American Philosophical Association Delphi project (Facione, Facione and Giancarlo, 1999). It was adapted to Turkish by Kökdemir (2003). To test the reliability 
of the inventory, the Cronbach's Alpha coefficients were calculated. It was found as .86 for the whole scale; .82 for inquisitiveness subscale while item-total correlation coefficients varied between .39-.75.

\subsection{General Self-Efficacy Scale}

General Self-Efficacy Scale (GSES) developed by Schwarzer and Jerusalem (1995) and adapted to over 25 languages was adapted to Turkish by Aypay (2010) in a study conducted on 693 students from three universities. To test the reliability of the scale, the Cronbach's Alpha coefficients were calculated, and the following results were found: .87 for the whole scale, .82 for learning and endeavour subscale with item-total correlation coefficients varying between $.68-.76 ; .75$ for ability and confidence subscale with item-total correlation coefficients varying between .60-.74.

\subsection{Data Analysis}

The data obtained through the Personal Information Form, Self-Directed Learning Readiness Scale, Critical Thinking and General Self-Efficacy Scale and the points obtained from the study were coded and entered into SPSS 20.0 package program through which the analyses were performed. The candidates' personal information and inventory total points, and factor points were presented by finding frequency (f) and percentage (\%) values. To indicate the relationship between the points obtained from the scales, Pearson's Moment-Product Correlation analysis (r) was conducted while multiple regression analysis was performed to determine whether the points are predictive of each other. $(\beta)$

\section{Findings}

Table 2. Descriptive statistics of the students' responses to the questionnaire

\begin{tabular}{lcccc}
\hline & N & Minimum & Maximum & X \pm SD \\
\hline Self-Directed Learning Readiness & 419 & 90.00 & 276.00 & $204.27 \pm 26.03$ \\
Critical Thinking & 419 & 53.00 & 265.00 & $213.59 \pm 31.77$ \\
General Self-Efficacy & 419 & 10.00 & 45.00 & $34.75 \pm 5.10$ \\
\hline
\end{tabular}

As is seen in Table 2, self-directed learning readiness among the participants was calculated as 204.27 on average while average scores for critical thinking and general self-efficacy were found as 213.59 and 34.75, respectively.

Table 3. Correlation Coefficients between the Students' Self-Directed Learning Readiness and Critical Thinking and General Self-Efficacy $(n=419)$

\begin{tabular}{|c|c|c|c|c|}
\hline & & 1 & 2 & 3 \\
\hline \multirow{3}{*}{$\begin{array}{l}\text { Self-Directed } \\
\text { Learning } \\
\text { Readiness }^{1}\end{array}$} & $\mathrm{r}$ & 1 & & \\
\hline & $\mathrm{p}$ & & & \\
\hline & $\mathrm{N}$ & 419 & & \\
\hline \multirow{3}{*}{ Critical Thinking $^{2}$} & $\mathrm{r}$ & $.624^{* *}$ & 1 & \\
\hline & $\mathrm{p}$ & .000 & & \\
\hline & $\mathrm{N}$ & 418 & 418 & \\
\hline \multirow{3}{*}{$\begin{array}{l}\text { General } \\
\text { Self-Efficacy }\end{array}$} & $\mathrm{r}$ & $.623^{* *}$ & $.347^{* *}$ & 1 \\
\hline & $\mathrm{p}$ & .000 & .000 & \\
\hline & $\mathrm{N}$ & 419 & 418 & 419 \\
\hline
\end{tabular}

Table 3 shows that there was a positive relationship between self-directed learning readiness and critical thinking $(\mathrm{r}=.624 \mathrm{p}=.000)$ while there was a high, positive significant relationship between self-directed learning readiness and general self-efficacy $(\mathrm{r}=.623 \mathrm{p}=.000)$. The Table also reveals a positive significant relationship between critical thinking and general self-efficacy $(\mathrm{r}=.345 \mathrm{p}=.000)$. 
Table 4. Regression Table for Students' Self-Directed Learning Readiness to Predict Critical Thinking and General Self-Efficacy

\begin{tabular}{|c|c|c|c|c|c|c|c|c|}
\hline & & B & $\mathbf{T}$ & $\mathbf{P}$ & $\mathbf{R}$ & $\overline{\mathbf{R}^{2}}$ & $\mathbf{F}$ & $\mathbf{P}$ \\
\hline \multirow{3}{*}{$\begin{array}{l}\text { Self-Directed } \\
\text { Learning } \\
\text { Readiness }\end{array}$} & \multirow[b]{2}{*}{$\begin{array}{l}\text { Critical } \\
\text { Thinking }\end{array}$} & \multirow[b]{2}{*}{.450} & \multirow[b]{2}{*}{12.217} & \multirow[b]{2}{*}{.000} & .711 & .505 & 211.647 & .000 \\
\hline & & & & & & & & \\
\hline & $\begin{array}{l}\text { General } \\
\text { Self-Efficacy }\end{array}$ & .416 & 11.283 & .000 & & & & \\
\hline
\end{tabular}

According to the analysis of Table 4, the model between self-directed learning readiness and critical thinking and general self-efficacy indicated a significant relationship $(\mathrm{R}=.711 \mathrm{R} 2=.505 ; \mathrm{p}<.001)$. T test results for the significance of regression coefficient were as follows: $(t=12.217 \mathrm{p}=.000)$ for critical thinking and $(\mathrm{t}=11.283 \mathrm{p}=.000)$ for general self-efficacy. It was found that the characteristics of self-directed learning readiness predicted the characteristics of critical thinking and general self-efficacy, and explained 50.5\% of total variance. $\mathrm{F}(2.415)=211.647 \mathrm{p}<.005)$.

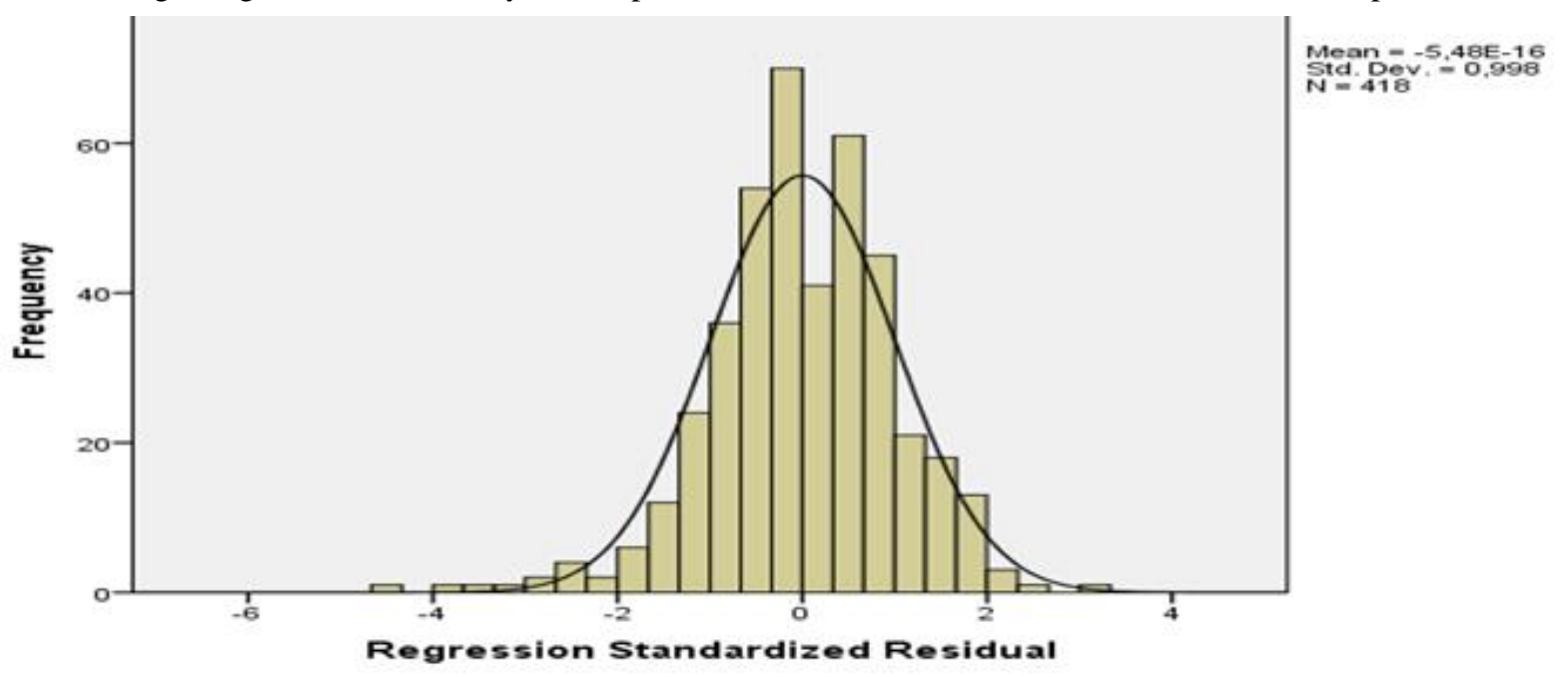

Figure 1. Dependent Variable Self-Directed Learning Readiness Histogram

\section{Discussion and Conclusion}

This study found a high significant relationship between self-directed learning readiness and critical thinking. Kreber (1993) examined the relationships between self-directed learning, critical thinking disposition, teaching philosophy and teaching behaviours of lecturers. According to the results of the study that applied both qualitative and quantitative methods, there was a high relationship between self-directed learning readiness and critical thinking disposition. In addition, it was found that lecturers were influential in ensuring students' self-directed learning readiness and critical thinking disposition.

Arpanantikul, Thanooruk \& Chanpuelksa (2006) conducted a study to investigate self-directed learning, critical thinking and self-esteem that were supposed to improve with problem-based learning skills. The results of this study conducted on candidate nurses indicated a positive significant relationship between self-directed learning readiness and critical thinking.

Kreber (1998) conducted a study to emphasize the importance of self-directed learning, critical thinking disposition and psychological state in higher education considering that they play a significant role in individuals' effective learning with the aim of revealing the relationships between them. According to the results of the study, self-directed learning, critical thinking disposition and psychological state were positively correlated while critical thinking disposition was also a significant predictor of self-directed learning.

In their study aiming to explore the relationship between candidate nurses' critical thinking ability and self-directed learning competency, Fengpeng, Ping \& Xueqin (2009) found a high relationship between self-directed learning readiness and critical thinking disposition. They reached the conclusion that candidate nurses' critical thinking and self-directed learning skills should be improved for their cognitive development. 
In another study, Yang, Lee, Sim, Park, Nam \& Kim (2012) explored nursing students' academic achievement, self-directed learning and critical thinking disposition levels according to learning styles. The study conducted on 240 nursing students found a relationship between self-directed learning readiness and critical thinking disposition.

Furthermore, Tabatabaei \& Parsafar (2012) examined the impact of critical thinking on self-directed learning in terms of foreign language learning in secondary school students. The test result obtained from experimental group indicated that there was a relationship between self-directed learning and critical thinking and critical thinking enhanced self-directed learning.

It is seen that the results of the studies in literature are compatible with the findings of our study. Just as the fact that individuals capable of managing their own learning efficiency assess different aspects and defects of the subject in question in the process of acquiring new information or in every question to be answered and make necessary criticisms is an expected action inherent to such people, physical education students' taking practice-based courses and having an active athlete life may have helped them to become individuals who can maintain their lives and approach things with an inquisitive eye.

This study found a high significant relationship between self-directed learning readiness and general self-efficacy. The study conducted by Şahin (2010) also revealed a high significant relationship between self-directed learning readiness and general self-efficacy scores of primary school classroom teachers.

Similarly, Hoban \& Serland (1998) conducted a study to display the relationship between self-directed learning readiness and self-efficacy. The researchers who also developed a scale called "Self-Efficacy for Self-Directed Learning Questionnaire" concluded that there was a statistically significant relationship between self-directed learning readiness and self-efficacy. They also stated that self-efficacy was important for self-directed learning readiness.

Ponton, Derrick, Confessore \& Rhea (2005) conducted a study aiming to explore the relationship between the characteristics of autonomous learners and self-efficacy by collecting data from 82 adults through 5 different measuring instruments. According to the results, they maintained that self-efficacy was an important variable for the students who learn autonomously to continue their learning, but it was not adequate on its own and thus, the process should be supported by environmental contexts as well.

In another study, Lema \& Agrusa (2006) examined the effect of self-efficacy and industry experience on self-directed learning readiness among hospitality industry college students. At the end of the study, they found that self-efficacy was a significant predictor of self-directed learning readiness.

In their study, Bijker, Klink \& Boshuizen (2010) studied the constructs affecting self-efficacy, self-regulating and self-directing learning capabilities, academic and career performances in adult individuals' career processes. The result obtained through structural equation model suggested that self-directing learning was a two-dimensional system, and self-regulating and self-efficacy acted as significant predictors of self-directing learning.

Finally, Hughes (2010) conducted a cross-cultural study to reveal the relationship between career decision self-efficacy and self-directed learning readiness among female university students. The study found a significant difference in favour of the African American university students while also discovering a relationship between self-directed learning readiness and self-efficacy.

Like our study, the studies in literature indicate that individuals with high general self-efficacy are more ready for self-directed learning. The participation of the students in the School of Physical Education in activities that improve their self-efficacy (competitions, refereeing, applied courses, etc.) may have increased their self-directed learning disposition.

As for the relationship between critical thinking and general self-efficacy, a significant relationship was revealed. In their study on candidate teachers, Kezer et al. (2016) found a linear proportional relationship between critical thinking and self-efficacy. Phan (2009) also found a positive significant relationship between self-efficacy and critical thinking. Wanga \& Yi Wub (2008) concluded that self-efficacy was a significant predictor in using high level learning ideas such as critical thinking. Self-efficacy involves questioning and choosing the one that suits you best. In this case, we believe that the students who participated in this study may have preferred to scrutinize or question the subjects with their self-confidence and self-efficacy.

The overall results of our study suggest that there was a significant relationship between self-directed learning and critical thinking and general self-efficacy, explaining 50.5\% of the variance. Considering these results, we can say that we need education systems that will raise individuals who are capable of organizing their own learning, assess things from different perspectives and also question them while recognising their own competences and deficiencies 
in today's information age. While determining long term education policies, efforts to improve such skills and increase students' awareness will make a considerable contribution to raising more authentic and qualified individuals.

\section{Recommendations}

1. Due to their status, teachers are quite effective in students' having self-directed learning readiness. Thus, training should be provided to make teachers role models and necessary updates should be made in in-service trainings.

2. To get students acquire and improve self-learning skills, educational and training programs that improve their cognitive and emotional development should be held while school, school administrators and teachers that play a prominent role in students' development should endeavour to provide students with self-directed learning readiness and self-directed learning skills.

3. Planned activities beginning from pre-school period to the university should be included in educational curricula so that students acquire self-direction skills.

4. Research should be conducted to examine other variables that may have an impact on self-directed learning.

\section{Limitations}

1. The sample of the study could be expanded to better reflect the research population.

2. Other variables that can affect critical thinking and self-adequacy could be included in the study.

3. Due to potential social, economic and environmental changes, the same scales could be conducted on the same respondents again to check the results. As the scales used in the study were not intended for the Turkish society, their adaptations may not reflect the research population entirely.

\section{References}

Arpanantikul, M. Thanooruk, R. \& Chanpuelksa, P. (2006). Self-Directed Learning Readiness, Critical Thinking Skill, and Self Esteem in Nursing Students Studying. Thai journal of Nursing research, 10, 59-72.

Aypay, A. (2010). Genel Öz Yeterlik Ölçeği'nin (GÖYÖ) Türkçe’ye Uyarlama Çalışması İnönü Üniversitesi Eğitim Fakültesi Dergisi, 11(2), 113-131.

Bandura, A. (1997). Self-Efficacy: The Exercise of Control. New York: NY: W. H. Freeman and Company.

Bijker, M. M. Van der Klink, M. R. \& Boshuizen, H. P. A. (2010). Modelling selfefficacy, self-regulation, self-directed learning and career processes of adult professionals and relations with learning outcomes and labour market success. Learning and Professional Development, Munich, Germany.

Coşkun, Y.D. \& Demirel, M. (2012). Üniversite Öğrencilerinin Yaşam Boyu Öğrenme Eğilimleri. Hacettepe Üniversitesi Eğitim Fakültesi Dergisi, 42, 108-120.

Cresson, C.J. \& Dean, G.,J. (2000). Lifelong Learning and Adult Educators' Beliefs: Implications for Theory and Pratice. PAACE Journal of Lifelong Learning, 9, 87-98.

Doğan, E. (Ocak 2002). Eğitimde Küreselleşme. Eğitim Araştırmaları, 6, 87-98.

Facione, P. A. Facione, N. C. \& Giancarlo, C. A. F. (1999). Professional Judgment and the Disposition Toward Critical Thinking. California Academic Press.

Fengpeng, L. Ping, L. \& Xueqin G. (2009). Relationship Between Critical Thinking Ability and Self-directed Learning Competence of ICU Nurses. Journal of Nursing Science, 3, 4.

Fisher, M. King, J. \& Tague, G. (2001). Development of a self-directed learning readiness scale for nursing education. Nurse Education Today, 21, 516-525. https://doi.org/10.1054/nedt.2001.0589

Gürlen, E. (2011). Probleme Dayalı Öğrenmenin Öğrenme Ürünlerine, Problem Çözme Becerilerine, Öz-Yeterlik Alg1 Düzeyine Etkisi. Hacettepe Üniversitesi Eğitim Fakültesi Dergisi, 40, 221-232.

Hendricson, ADEA Commission on Change \& Innovation (2007). Educational strategies associated with development of problem-solving, critical thinking, and self directed learning. Journal Dental Education, 70, 925-936.

Hoban, G. \& Sersland, C. (1998). Self-directed learning, learned or unlearned. İçinde H. B. Long \& Associates (Eds.). Developing paradigms for self-directed learning (pp. 107-204). Norman, OK: Public Managers Center.

Hughes, G. (2010). The relationship between career decision self-efficacy and selfdirected learning amongst female 
university students : a cross-cultural study. Faculty of Humanities University of Johannesburg.

Karasar N. (2007). Bilimsel Araştırma Yöntemi (17.baskı), Ankara, Nobel Yayın Dağıtım: 49-53.

Kezer, F. Ugurlu, O. \& Alfirat, N. O. (2016). eleştirel düşünme eğilimi, genel öz yeterlik ve umutsuzluk arasındaki ilişkinin incelenmesi. Mustafa Kemal University Journal of Graduate School of Social Sciences, 13(34), 202-218.

Kökdemir, D. (2003). Belirsizlik Durumlarında Karar Verme ve Problem Çözme. (Yayımlanmamış Doktora Tezi). Ankara Üniversitesi, Sosyal Bilimler Enstitüsü, Ankara.

Kreber, C. (1993). The Association Of Facultv's Teaching Philosophy and Teaching Behaviour and Critical Thinking and Self-Direction In Learning. Master of Education Faculty of EducationBrock University St. Catharines, Ontario.

Kreber, C. (1998). The relationship between self-directed learning, critical thinking, and psychological type and some implications for teaching in higher education. Studies in Higher Education, 23(1), 71-86. https://doi.org/10.1080/03075079812331380502

Lema, D.J. \& Agrusa, J. (2006). Self-efficacy, industry experience, and the self-directed learning readiness of hospitality industry college students. International Society of Travel and Tourism Educators, 6(4), 37-50.

Merriam, S. B., Caffarella, R. S., \& Baumgartner, L. M. (2007). Learning In Adulthood: A Comprehensive Guide (3rd ed.). San Francisco, CA: John Wiley and Sons, Inc.

Merriam, S.B. Caffarella, R.S. \& Baumgartner, L.M. (2007). Learning in adulthood: A comprehensive guide . (3rd). San Francisco, CA: Jossey - Bass.

Murray, H. (2015). Lifelong Learning In The Twenty-First Century: An Investigation On the Interrelationships Between Self-Directed Learning and Lifelong Learning. Doctor Of Education, Union State and University, Cincinnati, Ohio

Özden, Y. (2005). Öğrenme ve Ögrretme. (7. Baskl). Pegem A Yayınc1lık. Ankara

Phan, H. P. (2009). Relations between goals, self-efficacy, critical thinking, and deep processing strategies: A path analysis. Educational Psychology, 29, 777- 799. https://doi.org/10.1080/01443410903289423

Ponton, M. K. Derrick, M. G. Confessore, G. J. \& Rhea, N. E. (2005). The role of self efficacy in autonomous learning. International Journal of Self-Directed Learning, 2(2),47-58.

Raidal, S. L. \& Volet, S. E. (2009). Preclinical Students' Predispositions Towards Social Forms Of Instruction and Self-Directed Learning: A Challenge For The Development Of Autonomous and Collaborative Learners. Higher Education: The International Journal of Higher Education and Educational Planning, 57(5), 577-596.Response to Lynn Waterhouse. Educational Psychologist, 41(4), 227-232. https://doi.org/10.1007/s10734-008-9163-z

Şahin, E. (2010). İlköğretim Sinıf Öğretmenlerinin, Öğretim Stili Tercihlerinin, Cinsiyetlerinin, Mesleki Kıdemlerinin, Özyeterlik Algılarının ve Özyönetimli Öğrenmeye Hazırbulunuşluk Düzeylerinin Mesleki Yeterlikleri Üzerindeki Etkisi. Doktora Tezi. Yıldız Teknik Üniversitesi, Eğitim Fakültesi, İstanbul.

Sariolghalam, T. Narges, E. \& Noruzi, F. (2010). A Survey on the Relationship between Critical Thinking and Self-Efficacy Case Study: Mathematic Students of Payam e Noor University in Maragheh. Studies in Mathematical Sciences, 1(1), 61-66.

Tabatabaei, O. \& Parsafar, S. M. (2012). The Effect of Self-Directed Learning on Critical Thinking of Iranian EFL Learners. Journal of Educational and Social Research, 2(2).

Tuncel, A. (2010). Kuantum Öğrenme. İçinde Demirel, Ö.(Ed.), Eğitimde Yeni Yönelimler. (Sf.277-290).Ankara: Pegem A Yayıncilık.

Wanga, S.L. \& Yi Wub, P. (2008). The role of feedback and self-efficacy on web-based learning:The social cognitive perspective. Computers \& Education, 51, 1589-1598. https://doi.org/10.1016/j.compedu.2008.03.004

Wiley, K.R. (1982). Effects of a self-directed learning project and preference for structure on self-directed learning readiness. In Proceedings of the 23rd Annual Adult Education Research Conference (pp. 227-232).

Yang S. Ha, E. Lee, O. Sim, I. Park, Y. Nam, H. \& Kim, J. (2012). Academic Achievement, Self-directed Learning, and Critical Thinking Disposition According to Learning Styles of Nursing Students. Journal of Korean Academy of Fundamentals of Nursing, 19, 3. https://doi.org/10.7739/jkafn.2012.19.3.334 